\title{
PERILAKU KERJA GURU BIMBINGAN KONSELING LAKI-LAKI DAN PEREMPUAN TINGKAT SLTA DI JAKARTA
}

\author{
Esther Widhi Andangsari \\ Jurusan Psikologi, Fakultas Psikologi, Universitas Bina Nusantara \\ Jln. Kemanggisan Ilir III No.45, Kemanggisan, Palmerah, Jakarta Barat 11480 \\ esther@binus.edu
}

\begin{abstract}
ABSTRAK
Article presented performance behaviour among high school teachers in Jakarta, especially in their roles as counsellor based on the government's qualification and competences, especially in their empathy and persuasion. The research also wants to see the difference between male and female teachers' behaviour as counsellor, so that the schools are more serious in selecting and developing their teacher counsellor. Using DISC assessment tool for 68 teachers, consisting of 14 male and 54 female teachers, it is indicated that 26,47\% of them meet the government qualification, those are both empathy and persuasion qualifications. Empathy qualification is possessed by male and female teachers, even male teacher is more persuasive than male teacher who have dominant communication behaviour. In general, the research presents 13 behaviour styles.
\end{abstract}

Keywords: counsellor, counsellor teacher, school counsellor, performance behaviour

\begin{abstract}
ABSTRAK
Artikel menggambarkan perilaku kerja di kalangan para guru BK SLTA di Jakarta khususnya dalam peran mereka sebagai konselor di sekolah, apakah perilaku kerja mereka memenuhi kualifikasi atau kompetensi yang ditetapkan oleh pemerintah?, khususnya kualifikasi empati dan persuasi dalam konseling. Selain itu, penelitian juga ingin melihat perbedaan perilaku kerja guru BK laki-laki dan perempuan dalam menjalankan profesi mereka sebagai seorang konselor. Sehingga diharapkan dari penelitian ini muncul keseriusan dari pihak sekolah untuk memprioritaskan pemilihan dan pengembangan diri guru BK tersebut. Dengan menggunakan metode asesmen alat ukur DISC terhadap 68 guru BK yang terdiri atas 14 guru BK laki-laki dan 54 guru BK perempuan, diketahui bahwa perilaku kerja guru BK di Jakarta memenuhi kualifikasi yang ditetapkan oleh pemerintah sebagai konselor sekolah ada 26,47\%, yaitu kualifikasi empati sekaligus persuasi yang baik. Antara guru BK perempuan dan guru BK laki-laki ternyata sama-sama memiliki kualitas empati yang baik. Bahkan, guru BK laki-laki lebih baik dalam mengarahkan para siswa secara persuasif daripada guru BK perempuan yang berperilaku komunikasi dominan. Secara keseluruhan, penelitiani menghasilkan 13 style perilaku kerja.
\end{abstract}

Kata kunci: bimbingan konseling, guru BK, konselor sekolah, perilaku kerja 


\section{PENDAHULUAN}

Materi Bimbingan Konseling (BK) di SMA dianggap penting, mengingat fungsinya untuk membantu siswa agar dapat menjadi siswa yang mandiri, termasuk dalam belajar dan juga mengambil keputusan mengenai karir dan studi lanjut mereka. Mengingat fungsinya yang penting ini, dari sisi internal dituntut sosok guru BK yang memenuhi kompetensi sebagai seorang konselor yang baik. Dari sisi eksternal, dituntut adanya pengawasan yang bermutu terhadap para konselor sekolah ini (Dollarhide and Miller, 2006). Magnuson, Norem, dan Bradley (2001) menegaskan bahwa ketika seorang konselor tidak disertai oleh persiapan dan pengawasan yang bertanggung jawab, maka sesungguhnya institusi yang bersangkutan kehilangan kesempatan untuk memperoleh konselor yang berkualitas pada generasi berikutnya (Dollarhide and Miller, 2006).

Merujuk Standar Kualifikasi Akademik dan Kompetensi Konselor dari Lampiran Peraturan Menteri Pendidikan Nasional Nomor 27 tahun 2008 tanggal 11 Juni 2008, dikatakan bahwa kualifikasi konselor memiliki keunikan konteks tugas dan ekspektasi kinerja. Dijelaskan juga disitu bahwa konteks tugas konselor berada dalam kawasan pelayanan, yang bertujuan mengembangkan potensi dan memandirikan konselor dalam pengambilan keputusan dan pilihan untuk mewujudkan kehidupan yang produktif, sejahtera, dan peduli kemaslahatan umum.

Seorang guru BK yang juga adalah seorang konselor dituntut memiliki kompetensi profesional yang mampu menunjukkan integritas dan stabilitas kepribadian yang kuat, antara lain seorang yang ramah, sabar, empati, dan konsisten (Peraturan Menteri Pendidikan Nasional Nomor 27 tahun 2008). Dengan ditetapkannya peraturan pemerintah mengenai standar kualifikasi konselor sekolah tersebut, dapat dipahami bahwa profesi guru BK merupakan profesi yang penting dan benar-benar harus dijalankan oleh orang-orang yang berkualitas.

Namun, dari pengalaman berinteraksi dengan beberapa guru BK di Jakarta, peneliti mendapat informasi bahwa ada sekolah yang memilih guru BK seenaknya tanpa mempedulikan kualitas guru tersebut karena dianggap BK merupakan selingan, bukan hal yang utama untuk diperhatikan. Selain itu, ada kesan bahwa sepertinya yang tepat memenuhi kompetensi sebagai seorang guru BK adalah perempuan. Peneliti sangat jarang melihat guru BK laki-laki di beberapa sekolah. Ada anggapan bahwa sekolah lebih menyukai untuk mempekerjakan perempuan sebagai guru BK daripada laki-laki sehingga memunculkan pertanyaan, apakah betul guru BK perempuan dinilai memiliki kompetensi yang lebih baik sebagai seorang konselor daripada guru BK laki-laki. Atau dengan kata lain, apakah perilaku kerja guru BK perempuan lebih memenuhi kualifikasi yang diinginkan daripada guru BK laki-laki. Selain itu, sebelumnya juga perlu ditelusuri bagaimana sesungguhnya perilaku kerja guru BK berdasarkan hasil asesmen. Apakah perilaku kerja guru BK SLTA di Jakarta sudah sesuai dengan kualifikasi yang diinginkan oleh pemerintah dalam menjalankan profesinya tersebut atau belum.

Pada kenyataannya, literatur dalam negeri belum banyak yang membahas mengenai guru BK atau mengenai konselor sekolah dibandingkan literatur asing. Mencermati literatur dalam negeri mengenai guru BK ini, peneliti menemukan satu penelitian dalam sebuah skripsi yang pernah dilakukan di Semarang mengenai persepsi klien atau siswa terhadap guru BK (Solehhati, 2005). Melalui penelitian kuantitatif terhadap 99 guru BK se-Semarang ini, diperoleh hasil bahwa ada perbedaan yang signifikan mengenai efektifitas layanan konseling individual berdasarkan pengalaman kerja dan tingkat pendidikan guru BK menurut persepsi siswa sebagai klien. Selain itu, berdasarkan hasil penelitian Solehhati (2005) tersebut, juga ditemukan bahwa tidak ada perbedaan yang signifikan antara gender guru BK dengan keefektifan guru BK tersebut melakukan layanan konseling individual berdasarkan persepsi siswa. Penelitian di Semarang tersebut semakin mendorong peneliti untuk mencari tahu bagaimana perilaku kerja sesungguhnya yang dimiliki oleh para guru BK di Jakarta. Bukan berdasarkan persepsi klien atau siswa, tetapi nyata berdasarkan hasil asesmen yang dilakukan terhadap guru BK di Jakarta. 
Mencoba menelusuri pemikiran tersebut, peneliti ingin melihat gambaran perilaku kerja guru BK SLTA di Jakarta, secara khusus faktor kecakapan dalam mempengaruhi orang lain serta kemauan untuk mendengar orang lain atau empati. Di mana diasumsikan bahwa kedua faktor tersebut merupakan kompetensi atau kualifikasi penting yang dibutuhkan sebagai seorang guru BK yang berperan sebagai konselor di sekolah.

\section{METODE PENELITIAN}

Dalam penelitian ini, untuk mendapatkan gambaran mengenai kualifikasi guru BK yang sudah diuraikan di atas, dilakukan melalui pendekatan asesmen psikologis. Alat ukur yang digunakan adalah DISC. DISC sendiri merupakan alat asesmen dasar yang dapat digunakan untuk memetakan profil pekerjaan seseorang. Termasuk jenis alat asesment yang tertua dan paling banyak diteliti dalam pendekatan behavioral (Furlow, 2000). Alasan penggunaan alat asesmen, selain pada dasarnya memang mengukur perilaku kerja di mana guru BK dalam kapasitasnya juga adalah seorang pekerja, juga karena sifat alat asesmen ini yang cepat dan cukup mudah untuk digunakan, tergolong selfreported yang memudahkan peneliti untuk melakukan kontrol pada situasi tertentu yang memang diinginkan (Nofiar, 2005; Furr, 2009).

DISC dikembangkan oleh seorang psikolog berkebangsaan Amerika yang bernama William Moulton Marston, yang melakukan extensive observational research terhadap karakteristik, pola, dan respon dari ribuan orang dengan menggunakan kerangka teori dari Carl Jung (Nofiar, 2005). Ia mengemukakan empat kuadran kepribadian untuk mengukur perilaku kerja seseorang, yaitu D Dominance, I - Influence, S - Steadiness atau Stable, dan C - Correct atau Compliance (Furlow, 2000; Nofiar, 2005). Titik berat DISC adalah mengukur bagaimana seseorang bereaksi sehingga tidak mengukur kecerdasan, keterampilan, nilai-nilai, pengalaman, atau latar belakang pendidikan seseorang (Nofiar, 2005). Banyak orang yang menganggap DISC sebagai alat asesmen yang mengukur kepribadian. Yang dimaksud dengan kepribadian disini adalah behavior atau perilaku. Di mana behavior akan muncul sebagai hasil perpaduan dari kepribadian dengan lingkungan, termasuk tindakan dan respon yang muncul saat dihadapkan pada situasi sosial tertentu (Nofiar, 2005; Furr, 2009).

Dalam interpretasinya, orang yang memiliki faktor D yang tinggi digambarkan sebagai orang yang mampu mengarahkan orang lain, sementara orang yang memiliki faktor I yang tinggi dianggap orang-orang yang cakap dalam berbicara dan meyakinkan orang lain atau persuasi. Berbeda dengan orang yang memiliki faktor S yang tinggi. Orang tersebut memiliki gambaran sebagai orang yang cenderung pasif, tenang, dan mudah bekerja sama dalam tim. Orang yang memiliki faktor $\mathrm{C}$ yang tinggi memiliki gambaran sebagai orang yang fokus pada data dan cenderung perfectionist. Menurut DISC, orang dengan style D dan C merupakan orang-orang yang berorientasi pada pekerjaan. Sedangkan orang dengan style I dan S lebih berorientasi pada interaksi dengan orang lain.

Dalam penelitian dengan menggunakan alat asesmen DISC, profesi sebagai guru BK dinilai memiliki profil sebagai berikut (Gambar 1). 


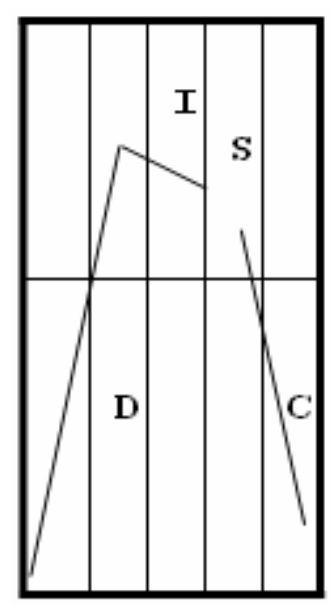

Gambar 1 Profil DISC Guru BK

Dari gambar di atas, dapat diketahui bahwa sebagai seorang guru BK yang berfungsi sebagai konselor sekolah, diharapkan faktor yang menonjol adalah faktor I kemudian diikuti oleh faktor S. Dengan demikian, dapat dijelaskan bahwa seorang guru BK yang memiliki kedua faktor I dan S yang cukup tinggi merupakan individu yang yang secara emosi dapat dengan mudah mendekati siswa yang dibimbingnya, menunjukkan pengertian dan afeksi, empati dan mau mendengarkan, mampu menunjukkan kehangatan dalam interaksinya, dan mempertahankan relasi interpersonalnya.

Pengambilan data dilakukan terhadap 68 guru BK SLTA se-Jakarta yang terdiri atas 54 guru BK perempuan dan 14 guru BK laki-laki. Para guru BK tersebut diundang datang ke Universitas Bina Nusantara kampus Anggrek dan diberikan asesmen DISC ini. Asesmen dilakukan secara klasikal dengan pertimbangan supaya lebih terjaga dalam pemberian instruksi dan penjelasan mengenai asesmen DISC ini, lebih praktis secara waktu serta tenaga.

Analisis dilakukan dengan berpedoman pada analisis alat asesmen DISC. Analisis dilakukan secara umum untuk mendapatkan gambaran perilaku kerja para guru BK secara keseluruhan untuk menjawab pertanyaan penelitian, "bagaimana perilaku kerja guru BK SLTA di Jakarta berdasarkan hasil asesmen DISC?”; dan "apakah sudah sesuai dengan kualifikasi yang ditetapkan oleh pemerintah, khususnya kualifikasi empati dan persuasi sebagai seorang konselor sekolah?”. Kemudian dilakukan analisis perbandingan antara guru BK laki-laki dan perempuan untuk menjawab pertanyaan penelitian, "apakah guru BK perempuan memiliki perilaku kerja yang lebih baik dalam melakukan konseling daripada guru BK laki-laki?”.

\section{HASIL DAN PEMBAHASAN}

Dari 68 guru BK yang mengikuti asesmen DISC, diperoleh beragam style perilaku kerja. Yang memiliki style advisor, yang diasumsikan dalam penelitian ini sebagai style ideal bagi seorang guru BK dengan perannya sebagai konselor ada 18 orang atau 26,47\% dari jumlah guru BK yang diteliti. Dengan kata lain, 26,47\% dari jumlah seluruh partisipan atau seperempat dari keseluruhan partisipan memiliki perilaku kerja sesuai dengan kualifikasi yang ditetapkan oleh pemerintah untuk menjalankan peran yang disandangnya. Berdasarkan hasil asesmen DISC, diperoleh 13 style perilaku kerja yang muncul di kalangan para guru BK se-Jakarta. Ke-13 style perilaku kerja secara detail dapat dilihat pada Tabel 1. 
Tabel 1 Hasil Keseluruhan Asesmen DISC

$$
\mathrm{N}=68 \text { guru } \mathrm{BK}
$$

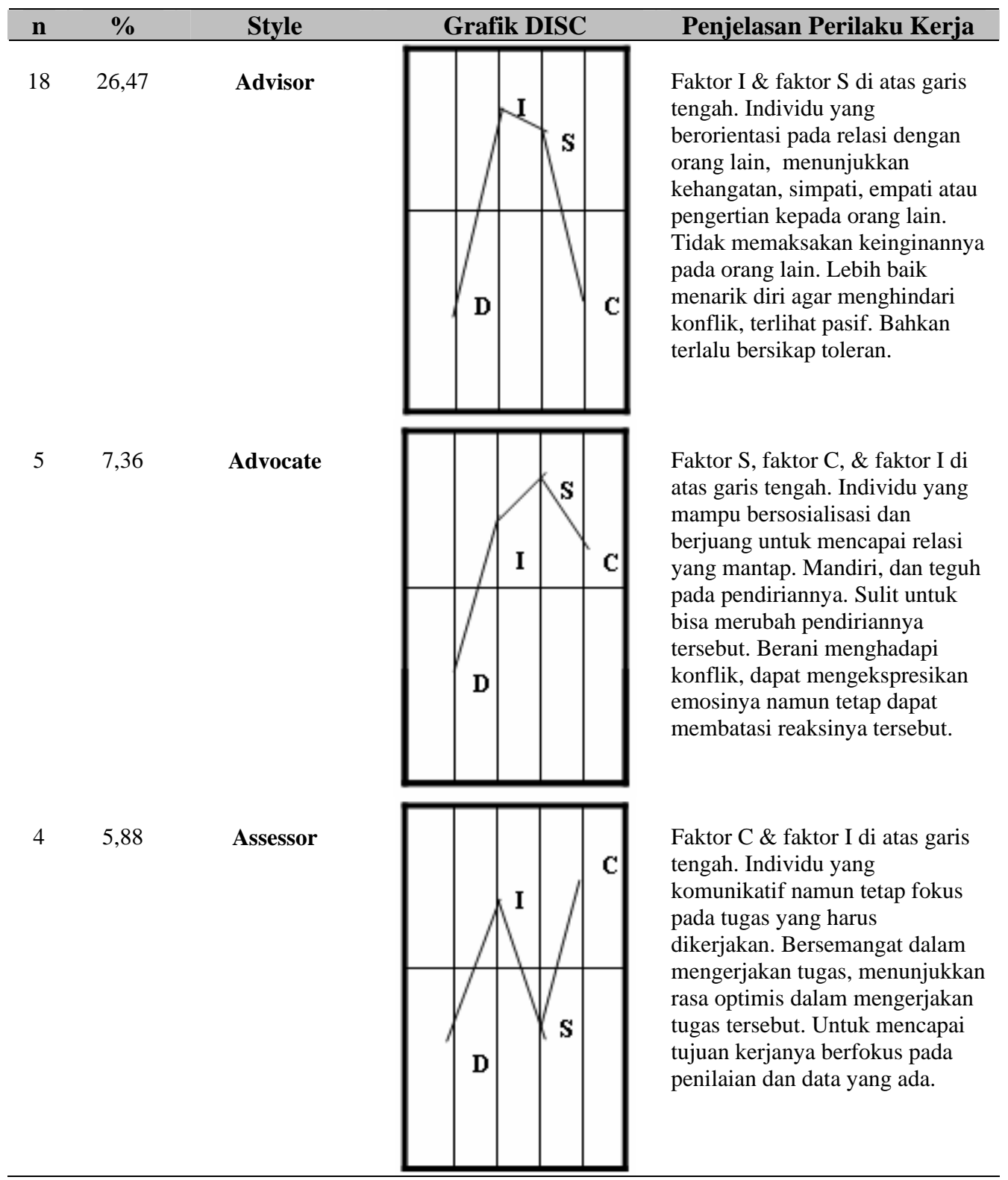




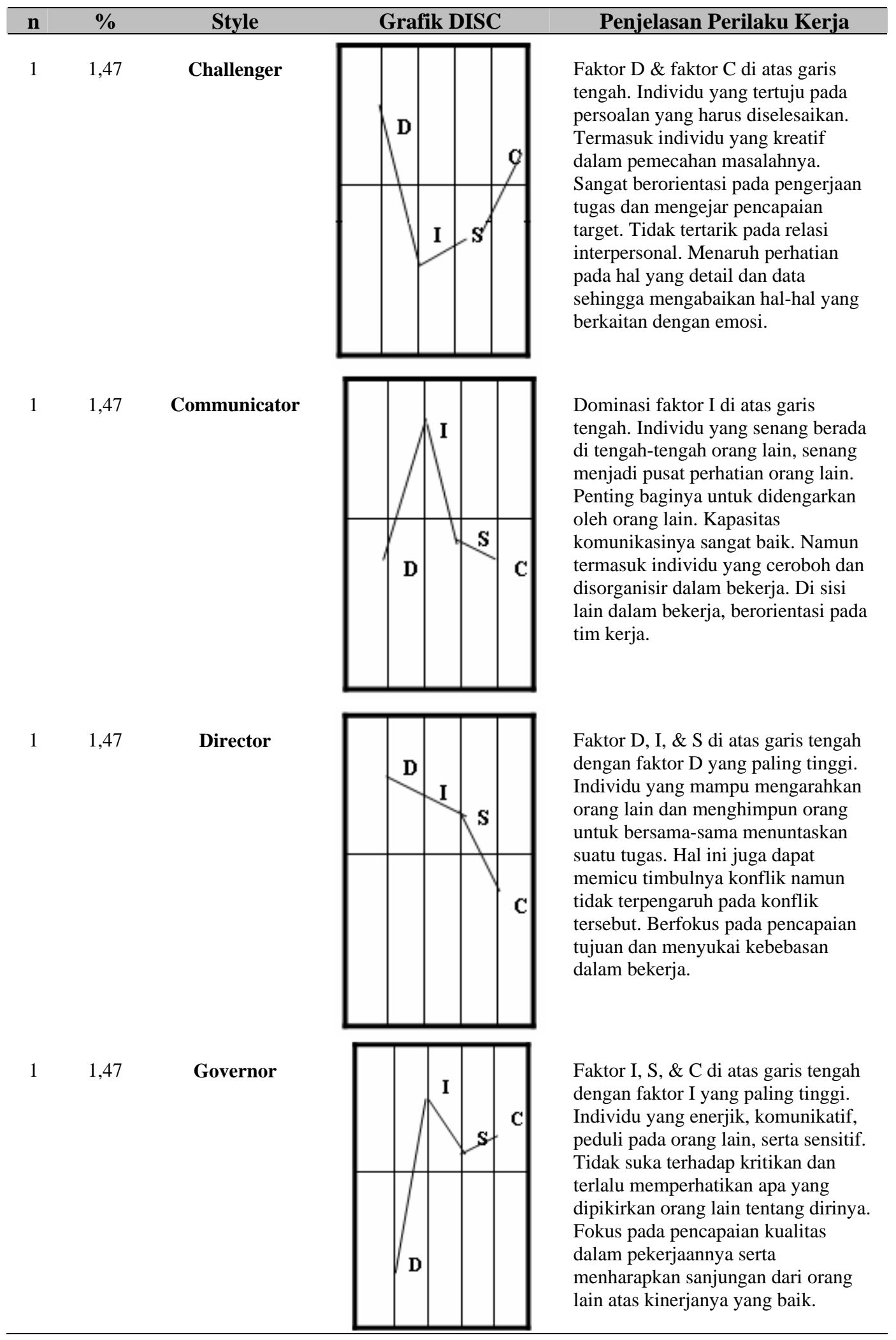




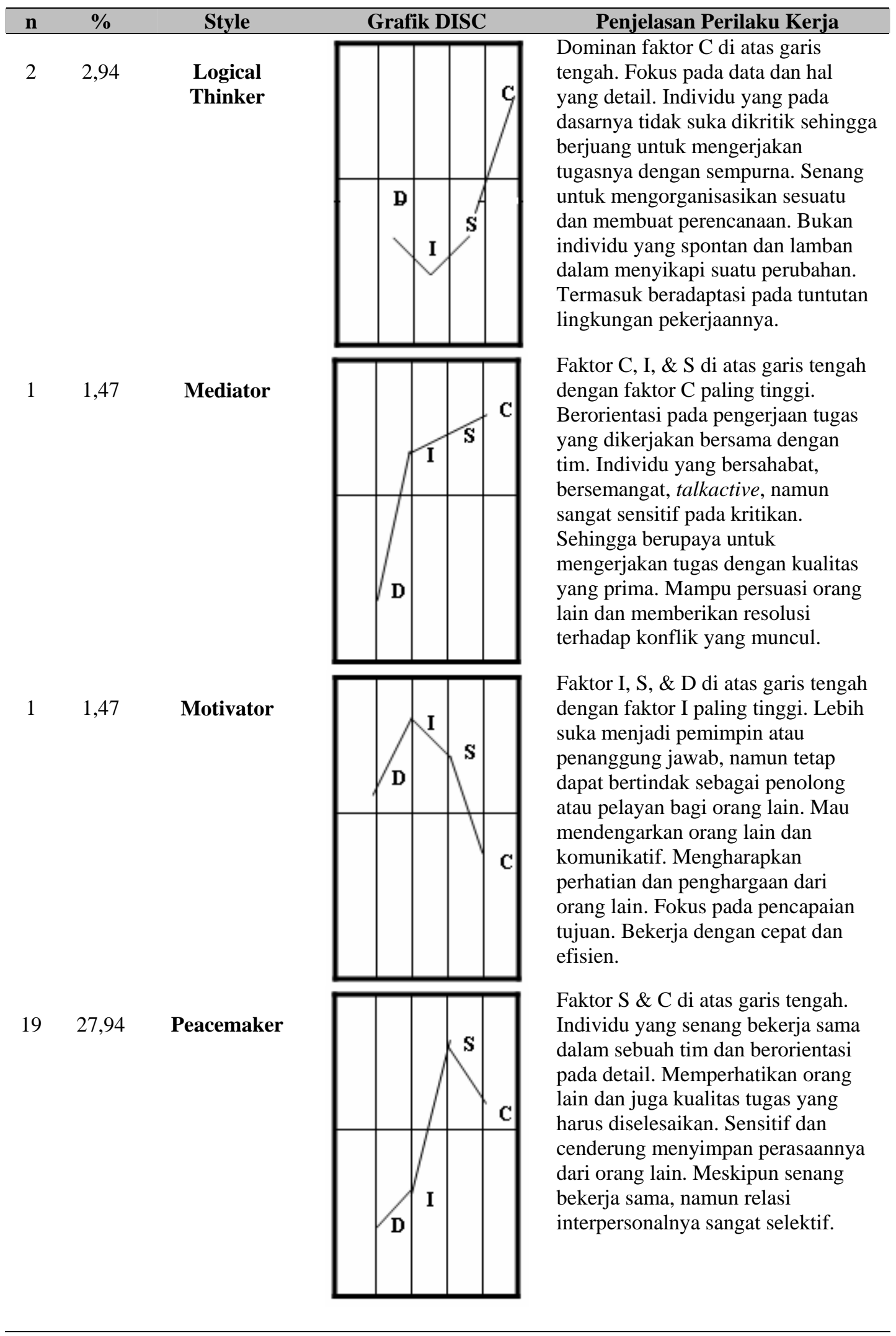




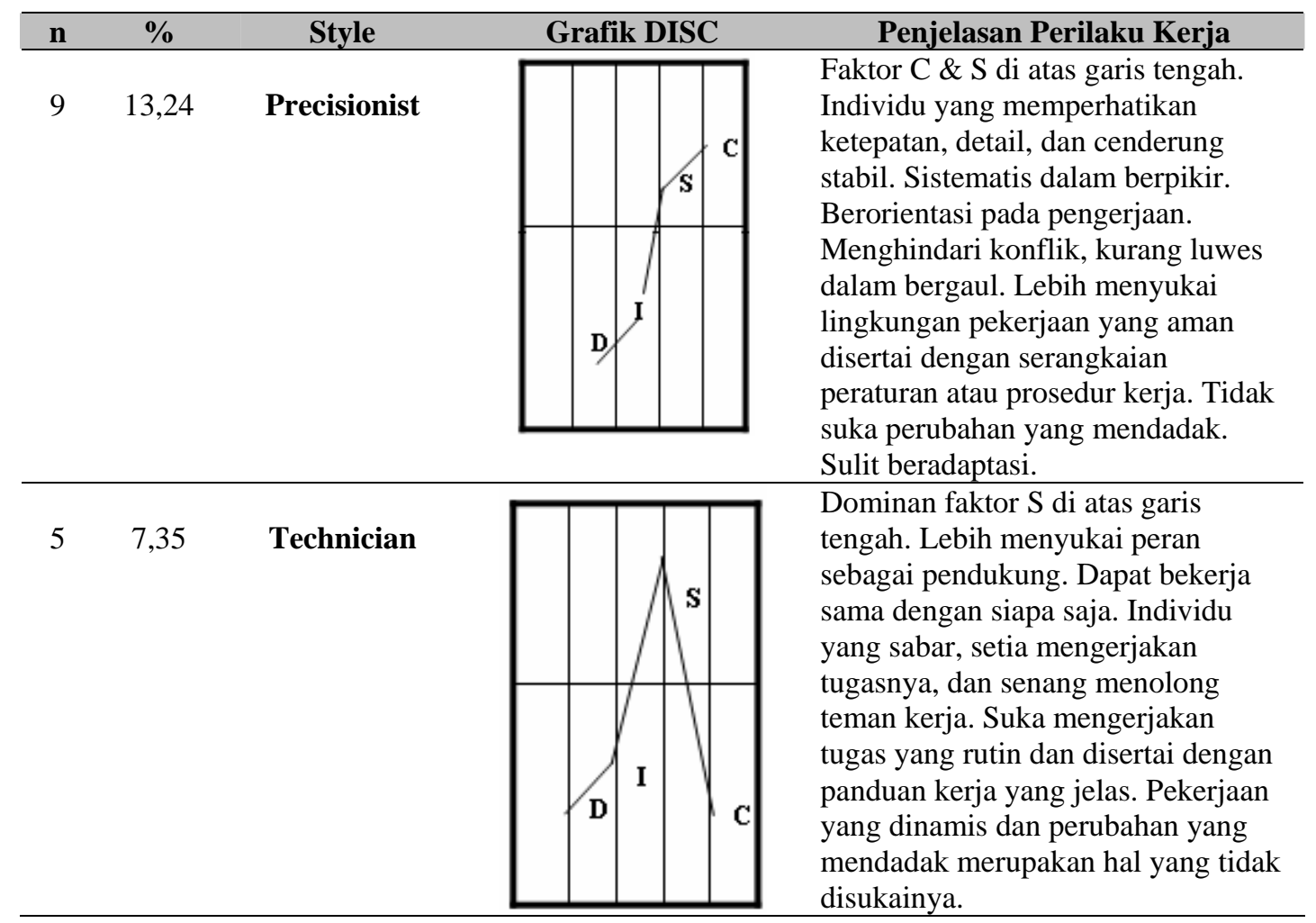

Dari hasil yang tertera pada Tabel 1, diperoleh data bahwa style perilaku kerja terbanyak yang dimiliki oleh para guru BK dalam penelitian ini adalah Peacemaker (27,94\%); di mana faktor S merupakan faktor yang paling tinggi, disertai dengan faktor $\mathrm{C}$ yang berada di atas garis tengah. Namun, faktor I justru berada di bawah garis tengah, bersamaan dengan faktor D. Dengan demikian, dapat dikatakan bahwa ada sebanyak 27,94\% guru BK di Jakarta dalam penelitian ini yang memiliki kapasitas melakukan empati pada siswa yang dibimbingnya, sensitif terhadap permasalahan para siswa, memperhatikan secara mendetail keterangan siswa, dan fokus pada tugasnya. Namun sayangnya, tidak dapat melakukan persuasi dan mengarahkan siswanya secara fleksibel.

Prosentase terbanyak kedua dalam penelitian ini adalah style advisor (26,47\%); merupakan style ideal atau style perilaku kerja yang diharapkan dimiliki oleh para guru BK yang berperan sebagai konselor. Faktor I dan faktor S berada di atas garis tengah sehingga dapat dikatakan bahwa ada sebanyak 26,47\% guru BK di Jakarta dalam penelitian ini yang memiliki perilaku mengarahkan siswa yang dibimbingnya secara fleksibel, mampu persuasi, dan megkomunikasikan alternatif pada siswa tersebut. Mereka juga adalah orang-orang yang mampu berempati, hangat dalam relasi interpersonalnya, mau mendengarkan siswa, dan senang untuk menjalin relasi yang dekat dengan para siswa.

Prosentase ketiga terbanyak dalam penelitian ini adalah style precisionist $(13,24 \%)$; di mana faktor C dan faktor S berada di atas garis tengah, sementara faktor I berada di bawah garis tengah bersamaan dengan faktor D; merupakan style perilaku kerja yang berorientasi pada pengerjaan tugas, cenderung perfeksionis, sulit menerima interupsi sehingga dapat dikatakan bahwa ada sebanyak 13,24\% guru BK yang justru memiliki perilaku kerja yang kurang luwes dalam berinteraksi dengan siswa di mana guru BK tersebut terkesan menjaga jarak dengan siswa yang dilayaninya, terpaku pada data yang disampaikan oleh siswa, namun kurang memperhatikan perasaan atau emosi siswa yang dibimbingnya. Mereka mampu berpikir secara sistematis persoalan yang disampaikan oleh siswa. Hanya saja tidak komunikatif dalam interaksi atau melakukan konseling dengan para siswa. 
Prosentase keempat terbanyak dalam penelitian ini adalah style advocate $(7,36 \%)$ dan style technician (7,35\%). Pada advocate, faktor S, C, dan I berada di atas garis tengah. Sedangkan pada technician, faktor S merupakan faktor yang dominan di atas garis tengah, faktor lainnya berada di bawah garis tengah. Kedua style ini memiliki satu kesamaan kecil, yaitu faktor S merupakan faktor yang lebih tinggi di antara faktor-faktor lainnya sehingga dapat dikatakan bahwa perilaku kerja terbanyak urutan ke-4 dari penelitian ini adalah para guru BK yang setia mengerjakan tugas yang harus dilakukannya dan senang untuk bekerja sama dengan orang lain. Perbedannya terlihat cukup banyak; di mana sebanyak 7,36\% guru BK di Jakarta dalam penelitian ini tidak hanya setia mengerjakan tugasnya dan mau bekerja sama dengan orang lain, tetapi mampu menjalin relasi yang mantap dengan para siswa dan mempertahankannya. Selain itu, para guru BK tersebut termasuk guru BK yang teguh dengan pendirian yang telah dibuatnya. Sulit bagi para siswa untuk dapat menggoyahkan pendirian tersebut, apalagi bila pendapat para siswa tersebut tidak didukung dengan data yang jelas. Sementara itu, ada 7,35\% guru BK di Jakarta dalam penelitian ini yang setia pada tugas yang harus dikerjakannya dan mau bekerja sama dengan orang lain. Namun, sayangnya tidak luwes dalam berkomunikasi, kurang punya inisiatif untuk menggerakkan para siswa. Guru BK seperti ini biasanya kurang senang terlibat dengan kegiatan para siswa yang sifatnya dinamis. Mereka lebih senang terlibat dalam aktifitas yang rutin.

Prosentase kelima terbanyak dalam penelitian ini adalah style assessor (5,88\%). Faktor C dan faktor I berada di atas garis tengah. Berdasarkan penjelasan mengenai style assessor ini, maka dapat dikatakan bahwa ada sebanyak 5,88\% guru BK di Jakarta dalam penelitian ini yang memiliki perilaku kerja terfokus pada tugas yang dikerjakannya, cermat mengenai data diri para siswa yang dibimbingnya serta mampu mengkomunikasikan hasil temuan atau persoalan yang dihadapi para siswa. Hanya saja dalam pelaksanaan konseling, termasuk guru BK yang kurang sabar, kurang dapat menunjukkan empati dan pemahaman yang mendalam terhadap persoalan yang dihadapi para siswa.

Style lainnya yang dimiliki oleh para guru BK di Jakarta dalam penelitian ini, mengingat prosentasenya yang minim, yaitu antara 1,47\% hingga 2,94\%, dapat dikategorikan menjadi tiga kategori besar. Pertama, faktor D yang lebih tinggi di antara faktor lainnya (Challenger dan Director); di mana guru BK pada kategori ini berorientasi pada pengerjaan tugas, mampu mengarahkan siswa untuk mengerjakan sesuatu, menyukai kebebasan dalam mengerjakan tugasnya, dan dalam berelasi dengan siswa cenderung memposisikan diri sebagai orang yang memiliki berkedudukan lebih tinggi daripada siswa. Kedua, faktor I yang lebih tinggi atau yang dominan di antara faktor lainnya (Communicator, Governor, dan Motivator); di mana guru BK pada kategori ini merupakan guru BK yang komunikatif, senang untuk berinteraksi dengan siswa, namun belum tentu berempati pada siswanya dan mau dengan sabar mendengarkan siswa, senang menjadi pusat perhatian orang lain serta guru BK yang bersedia terlibat dalam aktifitas siswa yang dinamis. Ketiga, faktor C yang lebih tinggi di antara faktor lainnya (Logical Thinker dan Mediator); di mana pada kategori ini guru BK terfokus pada data yang ada, pengambilan keputusan dan pemberian saran untuk para siswa berdasarkan data yang ada, sensitif, namun belum tentu punya kapasitas empati yang baik, cenderung terpaku pada kualitas yang prima dalam menuntaskan tugasnya serta kurang dapat beradaptasi terhadap situasi yang sering berubah-ubah.

Bila dilakukan analisis perbandingan perilaku kerja antara 14 guru BK laki-laki dan 54 guru BK perempuan, maka diperoleh hasil seperti yang tertera pada Tabel 2. 
Tabel 2 Hasil DISC Perbandingan antara Guru BK Laki-laki dan Guru BK Perempuan

\begin{tabular}{|c|c|c|c|c|}
\hline \multicolumn{2}{|c|}{ Laki-laki } & \multirow{2}{*}{ Style } & \multicolumn{2}{|c|}{ Perempuan } \\
\hline n & $\%$ & & n & $\%$ \\
\hline 6 & 42,86 & Advisor & 12 & 22,22 \\
\hline 2 & 14,29 & Peacemaker & 17 & 31,48 \\
\hline 2 & 14,29 & Precisionist & 7 & 12,96 \\
\hline 1 & 7,14 & Technician & 4 & 7,41 \\
\hline 0 & 0 & Advocate & 5 & 9,26 \\
\hline 0 & 0 & Assessor & 4 & 7,41 \\
\hline 0 & 0 & $\begin{array}{l}\text { Faktor I lebih tinggi atau dominan diantara faktor lainnya (Communicator, } \\
\text { Governor, Motivator) }\end{array}$ & 3 & 5,56 \\
\hline 1 & 7,14 & Faktor D lebih tinggi dari faktor lainnya (Challenger \& Director) & 1 & 1,85 \\
\hline 2 & 14,29 & $\begin{array}{l}\text { Faktor C lebih tinggi atau dominan dari faktor lainnya (Logical Thinker \& } \\
\text { Mediator) }\end{array}$ & 1 & 1,85 \\
\hline $\mathrm{N}=14$ & 100 & & $\mathrm{~N}=54$ & 100 \\
\hline
\end{tabular}

Dari data di atas, dapat diketahui bahwa style advisor sebagai style yang diharapkan ada pada diri guru BK lebih banyak dimiliki oleh para guru BK laki-laki (42,86\%) daripada guru BK perempuan $(22,22 \%)$ dalam penelitian ini; di mana guru BK laki-laki di Jakarta dalam penelitian ini memiliki perilaku kerja yang mau berempati, sabar, dan mampu mengkomunikasikan alternatif atau solusi dalam konseling. Style perilaku kerja guru BK perempuan lebih banyak ditunjukkan dalam style peacemaker (31,48\%); di mana para guru BK perempuan di Jakarta dalam penelitian ini memang memiliki kualifikasi empati yang baik, namun sayangnya tidak komunikatif dalam mengarahkan siswanya. Dari dua data ini, dapat diartikan bahwa guru BK laki-laki di Jakarta dalam penelitian ini ternyata memiliki perilaku kerja yang lebih baik sebagai seorang konselor, bila dibandingkan dengan guru BK perempuan. Para guru BK laki-laki dan perempuan sama-sama memiliki kualifikasi empati dan mau mendengarkan yang baik. Namun guru BK laki-laki ternyata lebih komunikatif dalam mengarahkan siswa ketimbang para guru BK perempuan. Tentu saja temuan ini dapat 'menggeser' anggapan mengenai guru BK laki-laki yang kurang luwes dan empati dalam melakukan konseling; di mana empati diasumsikan lebih banyak dimiliki oleh para guru BK perempuan.

Perbedaan lain yang dapat dilihat dari data pada Tabel 2 adalah guru BK perempuan yang memiliki perilaku komunikasi yang menonjol, ternyata kapasitas tersebut belum tentu disertai dengan kemauan untuk mendengarkan orang lain. Namun cenderung ingin tampil sebagai pusat perhatian orang lain, sementara tidak ada satu pun guru BK laki-laki dalam penelitian ini yang memiliki perilaku demikian. Hal ini ditunjukkan lewat data sebanyak 5,56\% guru BK perempuan memiliki faktor I yang lebih tinggi atau dominan di antara faktor lainnya.Perbedaan lain yang terlihat khas adalah dalam penelitian ini memang terlihat guru BK perempuan lebih fleksibel dan lebih hangat dalam menjalin relasi dengan para siswa. Hal ini ditunjukkan oleh data style advisor dan assessor serta faktor I yang lebih tinggi atau dominan di antara faktor lainnya didominasi oleh para guru BK perempuan, sementara guru BK pria memiliki ciri khas perilaku yang perfeksionis, fokus pada tugas yang harus dikerjakannya, berpaku pada data atau berpikir logis serta menyukai tugas yang menantang. Kondisi ini memang sesuai dengan anggapan kebanyakan orang mengenai ciri khas yang membedakan antara laki-laki dan perempuan.

Dengan demikian, dapat diketahui dalam penelitian ini bahwa kualifikasi empati untuk melakukan konseling sebagai bagian dari pekerjaan guru BK tidak dapat didominasi oleh guru BK perempuan. Guru BK laki-laki ternyata memiliki kualifikasi empati yang juga sama. Selain itu, guru BK laki-laki ternyata memiliki kualifikasi komunikasi atau mengarahkan siswa atau persuasi lebih baik daripada guru BK perempuan. Guru BK perempuan cenderung memiliki perilaku komunikasi yang mendominasi orang lain, yang ingin menjadi sorotan orang lain. Namun, guru BK perempuan lebih baik dalam menjalin relasi yang hangat dan dekat dengan siswa ketimbang guru BK laki-laki. Guru BK laki-laki terlihat lebih berpikir logis dan mengandalkan data dalam pemberian saran atau alternatif kepada para siswa yang dilayaninya. 


\section{SIMPULAN}

Setelah mendapatkan hasil dari penelitian ini, maka dapat disimpulkan sebagai berikut. Pertama, perilaku kerja guru BK di Jakarta dari penelitian ini belum seluruhnya menunjukkan perilaku kerja sebagai seorang konselor yang efektif atau belum memenuhi standar kualifikasi konselor sekolah yang ditetapkan oleh pemerintah seperti yang ditunjukkan dalam style advisor hasil asesmen DISC. Selain itu, guru BK di Jakarta lebih banyak menunjukkan perilaku yang mampu berempati terhadap para siswa yang dilayaninya, namun tidak dapat mengarahkan dengan kemampuan persuasi yang baik para siswanya tersebut seperti yang terlihat dari style peacemaker. Kedua, perlu dicermati bahwa cukup banyak guru BK tingkat SLTA di Jakarta yang memiliki perilaku yang kurang luwes berkomunikasi serta menjaga jarak dengan para siswa seperti yang ditunjukkan oleh style precisionist. Prosentasenya menduduki peringkat ketiga terbesar (13,24\%). Guru BK dengan perilaku seperti ini sulit untuk beradaptasi dengan siswa yang dengan kondisi emosional yang mudah berubah-ubah.

Ketiga, mengenai anggapan bahwa guru BK perempuan dinilai lebih sesuai untuk menjadi konselor daripada guru BK laki-laki, ternyata anggapan tersebut dapat dipatahkan. Guru BK laki-laki justru memiliki kualitas empati yang tidak berbeda dengan guru BK perempuan. Malahan guru BK laki-laki, berdasarkan hasil asesmen DISC ini menunjukkan perilaku komunikasi yang lebih persuasif dalam mengarahkan siswanya ketimbang guru BK perempuan. Guru BK perempuan cenderung lebih dominan dalam berkomunikasi dengan para siswa. Bahkan, guru BK laki-laki dalam penelitian ini terlihat memiliki kualifikasi yang lebih sesuai dengan tuntutan kualifikasi seperti yang ditetapkan oleh pemerintah daripada guru BK perempuan. Keempat, guru BK perempuan dalam menjalin relasi dengan para siswanya memang lebih hangat dan mampu menjalin relasi lebih dekat dengan para siswa ketimbang guru BK laki-laki. Kelima, guru BK laki-laki berdasarkan hasil asesmen DISC lebih berorientasi pada data dalam melakukan konseling.

Untuk memperoleh gambaran yang lebih menyeluruh terhadap guru BK SLTA se-Jakarta, penelitian selanjutnya dengan memperbesar subjek penelitian sangat disarankan. Selain itu, perlu dilakukan suatu penelitian yang lebih komprehensif mengenai jenis pendekatan yang dipilih oleh para guru BK dalam melakukan konseling. Dari hasil penelitian ini, sepertinya ada indikasi bahwa guru BK perempuan memilih pendekatan yang berorientasi pada relasi interpersonal dengan para siswa dalam menjalankan konseling. Sementara itu, guru BK laki-laki lebih memiliki pendekatan yang berorientasi pada pemikiran logis dan pengumpulan data dalam menjalankan konselingnya. Mengenai hal ini perlu dibuktikan lebih lanjut. Perlu juga diteliti lebih lanjut mengenai kemungkinan korelasi yang kuat antara pengalaman kerja dan perbedaan gender terhadap kualifikasi ideal seorang guru BK atau konselor sekolah. Tentunya disertai dengan jumlah subyek yang lebih besar untuk memperkuat dugaan ini.

Saran praktis yang dapat diterapkan oleh guru BK di Jakarta dari hasil penelitian ini adalah para guru BK sebaiknya lebih mengasah keterampilan empatinya serta kemampuan komunikasi dan persuasi yang lebih baik dalam menjalankan profesinya sebagai guru BK. Untuk itu, dituntut peran sekolah yang lebih serius memikirkan pengembangan kompetensi atau kualitas kerja para guru BK serta pihak sekolah perlu menetapkan skala prioritas, yang terutama untuk pemilihan atau penerimaan guru BK di sekolah; termasuk melakukan pengawasan melalui supervisi konselor sekolah yang lebih berpengalaman dan terampil agar para konselor sekolah memiliki sarana diskusi yang memadai untuk menjalankan tugasnya dengan maksimal (Dollarhide and Miller, 2006). 


\section{DAFTAR PUSTAKA}

Dollarhide, C. T., and Miller, G. M. (2006). Special section: Supervision in schools. Supervision for preparation and practice of school counsellors: pathways to excellence. Counsellor Education and Supervision, 45, 242-252, he American Counselling Association.

Furlow, L. (2000). Job profiling: Building a winning team using behavioural assessment. Journal of Nursing Administration, 30 (3), 107-111, Lippincott, Williams and Wilkins, Inc.

Furr, R. M. (2009). Personality psychology as a truly behavioural science. European Journal of Personality, 23, 369-401, John Wiley and Sons Ltd.

Nofiar, Y. (2005). DISC. The leading behavioural assessment tool. Mengukur Perilaku Kerja, Jakarta: Fakultas Ekonomi, Universitas Indonesia..

Peraturan Menteri Pendidikan Nasional Republik Indonesia Nomor 27 Tahun 2008. Standar kualifikasi akademik dan kompetensi konselor.

Solehhati, K. P. (2005). Persepi klien tentang keefektifan konselor dalam melaksanakan konseling individual ditinjau dari tingkat pendidikan, pengalaman kerja dan gender konselor di SMA Negeri se-kota Semarang Tahun Ajaran 2004/2005, Semarang: Jurusan Bimbingan dan Konseling, Fakultas Ilmu Pendidikan, Universitas Negeri Semarang. 